\title{
Kesusasteraan Melayu dan "Novel Persuratan": Satu Pengamatan Kritis Tentang Sambutan Terhadap Pujangga Melayu
}

\section{Malay Literature and "Novel of Letters": A Critical Observation of the Reception of Pujangga Melayu}

\author{
*NUDRA SHAFINI HALIS AZHAN \\ MOHD ZARIAT ABDUL RANI \\ SALMAH JAN NOOR MUHAMMAD \\ Department of Malay Language, Faculty of Modern Languages and Communication, \\ Universiti Putra Malaysia, 43400 Serdang, Selangor, Malaysia \\ *Corresponding author: nudraazhan@gmail.com
}

Published online: 31 May 2021

To cite this article: Nudra Shafini Halis Azhan, Mohd Zariat Abdul Rani and Salmah Jan Noor Muhammad. 2021. Kesusasteraan Melayu dan "novel persuratan": Satu pengamatan kritis tentang sambutan terhadap Pujangga Melayu. KEMANUSIAAN the Asian Journal of Humanities 28(1): 73-97. https://doi.org/10.21315/kajh2021.28.1.4

To link to this article: https://doi.org/10.21315/kajh2021.28.1.4

\begin{abstract}
This study problematises how the novel entitled Pujangga Melayu by Mohd Affandi Hassan has been showcased. In the publication of its second edition in 2017, Pujangga Melayu was consistently and explicitly promoted, both on its front cover and in its blurb, as a "novel of letters". Novel of letters is defined as a novel which displays thoughts/"discourse" as its main content. Prior to the second edition, the term novel of letters was never used in reference to the novel. This calls attention to the inclination of previous studies on the novel before 2017, particularly in summing up its strengths. The current study set out to analyse previous studies on Pujangga Melayu before 2017 and to summarise the strengths of the same novel based on findings of studies prior to 2017. The textual analysis that was carried out revealed that previous studies were inclined to showcase Pujangga Melayu with various labels, including "novel of discourse", "novel of knowledge" and "work of letters". Despite using different terms, the studies generally identified thought/discourse as the main content in the novel, and its narrative served as the medium in foregrounding thought/discourse.
\end{abstract}

Keywords and phrases: Malay literature, Pujangga Melayu, Mohd Affandi Hassan, genuine literature, novel of letters

(C) Penerbit Universiti Sains Malaysia, 2021. This work is licensed under the terms of the Creative Commons Attribution (CC BY) (http://creativecommons.org/licenses/by/4.0/). 


\begin{abstract}
Abstrak. Kajian ini merungkai permasalahan dalam soal pemeragaan novel Pujangga Melayu karya Mohd Affandi Hassan. Dalam penerbitan edisi kedua pada tahun 2017, Pujangga Melayu secara konsisten dan eksplisit diperagakan sebagai "novel persuratan" pada kulit depan dan rangsang sari novel. Novel persuratan ditakrifkan sebagai novel yang menjadikan pemikiran/wacana sebagai isian utama. Istilah novel persuratan tidak digunakan dalam pemeragaan novel tersebut sebelum edisi keduanya. Hakikat ini menarik perhatian terhadap kecenderungan kajian-kajian ilmiah sebelum tahun 2017 dalam merumuskan kekuatan karya berkenaan. Sehubungan itu, kajian ini menggariskan dua objektif iaitu untuk menganalisis kajian-kajian ilmiah terhadap Pujangga Melayu sebelum tahun 2017 dan untuk merumuskan kekuatan novel yang sama berdasarkan hasil dapatan kajian-kajian ilmiah sebelum tahun 2017. Hasil analisis mendapati bahawa kajiankajian ilmiah sebelum tahun 2017 cenderung memperagakan Pujangga Melayu dengan beberapa label, antaranya "novel wacana", "novel ilmu" dan "karya persuratan". Meskipun menggunakan istilah-istilah berlainan, namun rata-rata kajian mengenal pasti pemikiran/ wacana sebagai pengisian utama novel tersebut. Cerita dalam novel berkenaan pula lebih berfungsi sebagai wadah dalam mengutarakan pemikiran/wacana.
\end{abstract}

Kata kunci dan frasa: kesusasteraan Melayu, Pujangga Melayu, Mohd Affandi Hassan, persuratan baru, novel persuratan

\title{
Pengenalan
}

Pujangga Melayu merupakan sebuah novel tetralogi karya Mohd Affandi Hassan. Dalam kegiatan sastera Melayu masa kini, nama Mohd Affandi Hassan sudah sedia terpahat sebagai antara penulis prolifik yang telah menghasilkan sejumlah karya kreatif, terutamanya novel dan cerita pendek (Nur Fatiha Fadila 2014, 68; Nurul Hilwany 2017, 16). Selain karya kreatif, nama beliau juga sedia utuh sebagai seorang pengkritik sastera dan terkenal dengan gagasan pemikiran beliau iaitu "Persuratan Baru" (PB). Secara umumnya, PB merupakan sebuah gagasan pemikiran yang berusaha untuk menghidupkan semula tradisi persuratan Islam dalam kegiatan sastera Melayu masa kini. Dalam mengutarakan PB, beliau tidak hanya memanfaatkan tulisan-tulisan berbentuk ilmiah seperti buku dan makalah, bahkan juga tulisan-tulisan berbentuk kreatif seperti novel. Dalam konteks inilah, pengkajian terhadap Pujangga Melayu dianggap signifikan kerana novel tetralogi ini dianggap sebagai manifestasi konkrit PB yang disampaikan melalui karya kreatif. Kesignifikan ini jelas dengan adanya sejumlah kajian ilmiah yang mengkaji Pujangga Melayu sehingga kini lantas mewujudkan korpus penyelidikannya yang tersendiri, seperti yang akan dibicarakan lebih lanjut nanti.

Sebagai sebuah novel tetralogi, Pujangga Melayu menggabungkan empat buah novel yang setiap satu sebelumnya telah terbit secara mandiri. Novel Jejak Warisan setebal 201 halaman diterbitkan oleh Penerbit Tiga Puteri pada tahun 1994, dan 
diikuti dengan novel Citra Pujangga setebal 302 halaman yang diterbitkan pula oleh Penerbit Fajar Bakti Sdn. Bhd. pada tahun 1994. Pada tahun yang sama, novel Tampang Sasterawan setebal 233 halaman diterbitkan juga oleh Penerbit Fajar Bakti Sdn. Bhd., yang kemudiannya menerbitkan novel Wajah Pendeta setebal 395 halaman pada tahun 1996. Pujangga Melayu yang menggabungkan keempat-empat novel ini diterbitkan oleh Penerbit Fajar Bakti Sdn. Bhd. pada tahun 1997 dan mengandungi 714 halaman.

Dari segi pemeragaan novel seperti yang terserlah pada kulit novel dan rangsang sari (blurb), novel Jejak Warisan tampil dengan rekaan kulit novel berwarna kuning gading, dengan rangsang sari yang antaranya tertera ayat dalam petikan berikut:

Novel ini adalah sebuah karya anti-sastera yang hebat... Dengan novel
ini, Affandi ingin mengembalikan martabat persuratan Melayu ke
tempatnya yang sah sebagai pewaris sastera Islam...menggabungkan
dengan mantap aspek intelektualisme, hikmah, seni mengarang, dan
semangat Islam sejati...untuk memenuhi gagasan beliau tentang
persuratan dan estetika Islam yang terdapat dalam bukunya Pendidikan
Estetika daripada Pendekatan Tauhid (1992). (Mohd Affandi 1994a)

Petikan rangsang sari berkenaan dengan jelas mengandungi beberapa istilah yang diperagakan sebagai antara kekuatan novel Jejak Warisan. Antara kekuatan tersebut ialah sifat novel yang dianggap sebagai sebuah "karya anti-sastera" yang dikatakan mengandungi "intelektualisme" dan "hikmah".

Merujuk kepada Citra Pujangga, rangsang sari novel ini dilihat masih mengekalkan nada pemeragaan yang sama, terutamanya ketika soal perbezaan antara "sasterawan" dengan "pengarang" ditonjolkan melalui kutipan yang dipetik dalam novel itu sendiri, seperti berikut:

Saya fikir kita semua yang ada di sini hari ini, patut membuat azam baru, iaitu tidak lagi ingin jadi "sasterawan", tetapi berubah menjadi pengarang. Barulah termasuk dalam golongan ahli ilmu, yang jadi pewaris para nabi... Sasterawan itu berminat kepada kulit-kulit persoalan, kepada halhal remeh-temeh, kepada perkara-perkara yang membangkitkan hawa nafsu, bukan akal dan roh insan... Pengarang melambangkan kegiatan ilmiah dan kreatif yang bersifat dalaman, pemikiran, kerohanian, filsafat. Kerana itu pengarang tidak membicarakan hal-hal remeh-temeh seperti yang dilakukan oleh para sasterawan. Ikutilah dialog-dialog provokatif tentang berbagai persoalan penting dalam novel ini. (Mohd Affandi 1994b) 
Berdasarkan petikan ini, agak jelas bahawa sasterawan dikaitkan dengan kegiatan yang tidak bersifat ilmiah (disebut sebagai "membicarakan hal-hal remehtemeh"), berbanding pengarang yang mengarang karya-karya yang mengandungi pemikiran dan falsafah. Dengan pemahaman ini, maksud "karya anti-sastera" yang dilabelkan pada novel Jejak Warisan iaitu sebuah karya yang bersifat ilmiah kerana tidak "membicarakan hal-hal remeh-temeh" dapat difahami. Hakikat bahawa rangsang sari menyebut soal perbezaan antara sasterawan dengan pengarang merupakan antara isi kandungan utama novel, dengan sendirinya menyerlahkan kecenderungan untuk memperagakan Citra Pujangga sebagai sebuah novel yang bersifat ilmiah dan tidak "membicarakan hal-hal remeh-temeh".

Lanjutan daripada pengamatan tersebut, adalah penting untuk seterusnya mengamati rangsang sari novel Tampang Sasterawan yang secara berulang-ulang dan konsisten menyebut tentang "persuratan", sebagaimana yang jelas dalam petikan berikut:

Tampang Sasterawan adalah jilid ketiga daripada sebuah quartet yang membicarakan takrif pengarang dan falsafah persuratan Melayu. Jilid ketiga ini menghuraikan perbezaan konsep "persuratan" dengan "kesusasteraan", dan tempat sasterawan yang sebenarnya dalam masyarakat. Penulisnya menolak konsep "kesusasteraan", dengan mengemukakan falsafah persuratan. Menurut watak utama novel ini: "Hanya dengan berlandaskan falsafah persuratan yang betul saja barulah kita dapat menulis dengan berkesan... Kita harus membasmi khurafat dalam sastera kita... Kita harus menulis karya-karya persuratan, bukan lagi sastera. Menulis novel persuratan, bukan novel sastera”. Novel ini juga menghuraikan beberapa kriteria penting dalam penilaian hasilhasil persuratan [penekanan penulis dalam tulisan berhuruf condong]. (Mohd Affandi 1994c)

Petikan rangsang sari berkenaan jelas mengandungi istilah-istilah berkaitan persuratan seperti "falsafah persuratan", "konsep persuratan", "karya-karya persuratan", "hasil-hasil persuratan" dan "novel persuratan". Hakikat bahawa istilah-istilah ini dikatakan dibicarakan dalam novel, mencetuskan persepsi bahawa Tampang Sasterawan turut diperagakan sebagai novel ilmiah yang lahir daripada kegiatan persuratan, sama seperti Jejak Warisan dan Citra Pujangga.

Rangsang sari Wajah Pendeta pula dilihat masih cenderung memperagakan novel terakhir ini sebagai sebuah novel yang bersifat ilmiah, seperti dalam petikan berikut: 


\begin{abstract}
Novel ini membicarakan dengan mendalam peranan sebenar seorang pengarang, sambil mendedahkan kepalsuan para sasterawan. Ikutilah kisah-kisah menarik tentang Prof. Awang Yusuf dan keluarganya dan peranannya dalam membangun pemikiran baru. Novel ini adalah jilid keempat daripada satu quartet, oleh itu harus dibaca selepas Jejak Warisan, Citra Pujangga, dan Tampang Sasterawan [penekanan penulis dalam tulisan berhuruf condong]. (Mohd Affandi 1996)
\end{abstract}

Sifat ilmiah yang diperagakan itu umpamanya, jelas ketika rangsang sari menyebut tentang perbicaraan mendalam seorang pengarang. Hal yang sama turut jelas pada ungkapan "membangun pemikiran baru" bagi merujuk kepada kisah yang terkandung dalam novel. Keadaan ini lebih ketara dengan pembaca disarankan untuk membaca tiga novel awal iaitu Jejak Warisan, Citra Pujangga dan Tampang Sasterawan, sebelum membaca Wajah Pendeta. Hakikat bahawa Wajah Pendeta disarankan untuk dibaca selepas ketiga-tiga novel itu menyerlahkan kecenderungan rangsang sari untuk memperagakan Wajah Pendeta juga sebagai novel ilmiah. Pemahaman ini dapat diperkukuh dengan halaman pengenalan (halaman awal sebelum novel bermula) menampilkan frasa "Penyelesaian Abad 21" yang diikuti dengan petikan dialog yang berbunyi, "Karya-karya ayah untuk orang-orang yang berfikir, bukan untuk si pandir". Pengenalan sebegini jelas menunjukkan bahawa Wajah Pendeta diperagakan sebagai sebuah novel ilmiah.

Suatu perkara yang signifikan apabila keempat-empat novel berkenaan kemudiannya digabungkan menjadi sebuah tetralogi yang terbit pada tahun 1997 dengan judul baharu iaitu Pujangga Melayu. Pujangga Melayu edisi pertama tampil dengan rangsang sari yang secara menyeluruh merumuskan kekuatan keempat-empat novel yang digabungkan itu, seperti dalam petikan berikut:
Novel (Pujangga Melayu) ini membicarakan dengan mendalam teori Persuratan Baru yang dikemukakan oleh penulisnya dalam esei sanggahannya terhadap pandangan seorang profesor sastera... Novel ini merupakan sebuah novel pertama dalam bahasa Melayu yang membicarakan takrif pengarang dan kegiatan kepengarangan dalam Persuratan Melayu dan Islam. Melalui novel ini, Mohd Affandi Hassan memperkenalkan genre novel kritikan dalam Persuratan Baru yang dianjurkannya. (Mohd Affandi 1997)

Petikan rangsang sari tersebut antara lain menyebut tentang kekuatan Pujangga Melayu yang memperkatakan secara mendalam tentang PB, iaitu sebuah teori atau lebih tepat ialah gagasan yang dikemukakan oleh Mohd Affandi Hassan. Turut ketara ialah perakuan bahawa Pujangga Melayu merupakan "sebuah novel pertama dalam bahasa Melayu yang membicarakan takrif pengarang dan kegiatan 
kepengarangan dalam Persuratan Melayu dan Islam". Bahagian interior backflap kulit novel Pujangga Melayu edisi pertama yang turut mencatatkan ayat berikut, "Keempat-empat novel anti-sasteranya ini telah disatukan dalam Pujangga Melayu, sebagai rakaman persuratan", juga sama pentingnya. Sehingga kini, semua rangsang sari novel didapati menghadirkan beberapa ungkapan seperti "karya persuratan", "novel persuratan" dan "rakaman persuratan" bagi merujuk keempat-empat novel beliau yang dirangkumkan di bawah judul Pujangga Melayu.

Edisi kedua pula didapati secara eksplisit memperagakan Pujangga Melayu sebagai sebuah novel persuratan pada kulit depan novel, halaman awal, penerangan tentang siri penerbitan, prakata dan rangsang sari novel. Pada kulit depan novel misalnya, istilah novel persuratan digunakan pada nama siri yang menerbitkan Pujangga Melayu edisi kedua, iaitu Siri Novel Persuratan, dan istilah yang sama juga hadir pada halaman awal, selain turut dilengkapi dengan nama penerbit iaitu Wadi al-Irfan, tempat penerbitan iaitu Kuala Lumpur dan tahun terbit iaitu 2017. Penggunaan istilah novel persuratan pada Pujangga Melayu edisi kedua ini semakin menonjol dalam halaman awal, hlm. ix, iaitu sewaktu penerbit menyediakan penerangan ringkas berkenaan Siri Novel Persuratan, antara lain seperti berikut:
Istilah "novel persuratan" ini dicetuskan oleh Mohd Affandi Hassan ketika membahaskan Gagasan Persuratan Baru... Dalam usaha menghidupkan kembali tradisi persuratan Islam, konsep "novel persuratan" diajukan dengan falsafah serta ciri yang berbeza daripada novel-novel yang sedia terhasil dalam sastera Melayu moden. Perbezaan ini antaranya terletak pada "pemikiran" atau "wacana" (iaitu penghujahan idea-idea ilmiah) yang menjadi pengisian utamanya, di samping "cerita" yang hanya berperanan sebagai wadah untuk menyampaikan "pemikiran atau "wacana". (Mohd Affandi 2017, ix)

Berdasarkan petikan berkenaan, adalah jelas bahawa Siri Novel Persuratan diwujudkan berdasarkan istilah novel persuratan yang dicetuskan oleh Mohd Affandi dalam membicarakan tentang gagasan PB. Penerangan ini turut menyebut secara umum tentang dua ciri novel persuratan iaitu ciri pertama ialah pemikiran/wacana sebagai pengisian utama manakala ciri kedua ialah cerita yang hanya berfungsi sebagai wadah bagi mengutarakan pemikiran/wacana. Dengan dua ciri ini, novel persuratan dikatakan berbeza dengan novel-novel Melayu yang lain. Selain itu, kenyataan bahawa ciri novel persuratan yang mengutamakan pemikiran/wacana dan mengkesampingkan cerita itu adalah seiring dengan usaha untuk menghidupkan semula tradisi persuratan Islam, juga tidak kurang pentingnya. 
Seterusnya, pemeragaan eksplisit Pujangga Melayu edisi kedua sebagai novel persuratan semakin ketara pada bahagian prakata (hlm. xi) yang mengandungi kata aluan Mohd Affandi sebagai pengarang novel tersebut. Antara perkara yang relevan untuk dibangkitkan ialah pengakuan beliau sendiri bahawa Pujangga Melayu merupakan sebuah novel yang beliau ajukan sebagai novel persuratan iaitu novel yang mengutamakan pemikiran. Menurut beliau, sesuai dengan pemikiran yang menjadi keutamaannya, Pujangga Melayu edisi kedua dilengkapi dengan indeks yang memberi petunjuk terhadap idea-idea penting yang terkandung dalam novel. Berdasarkan pengamatan yang dilakukan, indeks yang dimaksudkan itu secara keseluruhannya mengandungi 78 daftar kata, dengan 19 daftar kata yang merujuk kepada idea-idea, antaranya seperti hakikat ilmu, sastera dan persuratan. Dalam prakata ini, beliau turut menggariskan ciri penting novel persuratan iaitu mengutamakan wacana daripada cerita, seperti dalam kenyataannya, "Saya namakan gaya dan teknik yang dipakaikan ini sebagai stylization of ideas (yang saya terjemahkan buat sementara sebagai 'siratan makna'). Gaya penulisan ini mengutamakan 'wacana' daripada 'cerita'. Inilah gaya 'novel persuratan' yang mengutamakan 'pemikiran' serta 'wacana'” (Mohd Affandi 2017, xi). Sebagai penutup, prakata ini diakhiri dengan penekanan tentang kepentingan novel persuratan yang diajukan sebagai salah satu bentuk penulisan yang difikirkan mampu untuk "mencerdikkan pelajar" (ungkapan Mohd Affandi). Menurut beliau, usaha ini penting kerana kesusasteraan Melayu moden telah dibanjiri dengan cerita-cerita yang mengkhayalkan serta tidak membangunkan pemikiran (Mohd Affandi 2017, xii-xiii).

Perihal yang semakin memperkukuh pemeragaan Pujangga Melayu edisi kedua sebagai novel persuratan ialah rangsang sari pada bahagian kulit belakang novel, yang pada asasnya membezakan antara novel persuratan dengan novel sastera, seperti berikut:

Dengan novel persuratan, aku maksudkan novel yang mementingkan hikmah, kebijaksanaan, ilmu, nasihat, petua, pengajaran, amaran tentang kebaikan dan keburukan. Sebuah novel yang tidak menjadikan khayalan sebagai dasar cerita, sehingga memungkinkan ditulis novelnovel tentang perkara-perkara yang berada di luar kemampuan akal manusia memahaminya, seperti tentang syurga dan neraka, kehidupan di dalam kubur dan hal-hal seumpama itu. Novel persuratan mengawal dengan ketat temanya, supaya tidak hanyut di alam khayal bersama emosi liar yang dipandu seluruhnya oleh iblis, seperti yang dibuat oleh para penulis novel sastera. Para penulis novel sastera mementingkan cerita, emosi, peristiwa yang aneh-aneh, watak yang juga aneh-aneh. Novel sastera tidak mementingkan idea. (Mohd Affandi 2017) 
Petikan tersebut dengan jelas melakarkan perbezaan antara novel persuratan dengan novel sastera. Novel persuratan difahami sebagai karya yang menitikberatkan ilmu dan pemikiran termasuk hikmah, kebijaksanaan dan pengajaran, dan justeru "mengawal ketat temanya" supaya tidak sematamata bercerita. Manakala, novel sastera pula difahami sebagai karya yang "mementingkan cerita" dan "tidak mementingkan idea", dan justeru menjadikan "khayalan dan emosi sebagai dasar cerita". Justeru, jelas kelihatan pada tahap ini bahawa kulit hadapan, halaman awal, prakata dan rangsang sari secara eksplisit memperagakan Pujangga Melayu edisi kedua dengan satu label yang tunggal, konsisten dan ketara iaitu novel persuratan.

\section{Permasalahan Kajian}

Pengamatan sebelum ini penting bagi menjelaskan cara novel Pujangga Melayu diperagakan secara konsisten dan eksplisit sebagai novel persuratan hanya dalam penerbitan edisi kedua yang terbit pada tahun 2017. Pengamatan berkenaan jelas mendapati bahawa sebelum edisi kedua, istilah novel persuratan belum lagi digunakan secara konsisten dan eksplisit. Sebaliknya, beberapa istilah lain seperti "karya persuratan", novel persuratan dan "rakaman persuratan" digunakan secara serentak dalam penerbitan edisi pertama novel tersebut pada tahun 1997. Tidaklah keterlaluan untuk mengatakan bahawa istilah-istilah ini rata-ratanya merujuk kepada novel persuratan. Penggunaan beberapa istilah secara tidak konsisten ini juga dapat dilihat pada novel-novel sebelumnya iaitu Jejak Warisan, Citra Pujangga, Tampang Sasterawan dan Wajah Pendeta ketika diterbitkan secara mandiri. Antara istilah yang digunakan ialah "novel anti-sastera" dan "karya sastera Islam". Dengan kata lain, istilah novel persuratan yang dilabelkan pada Pujangga Melayu hanya konsisten dalam penerbitan edisi kedua novel tersebut.

Seperti yang telah dijelaskan, novel Pujangga Melayu sehingga kini telah mendapat perhatian yang luas daripada para pengkaji, pengkritik dan sarjana sastera sehingga mewujudkan korpus penyelidikan yang tersendiri. Antara nama tersebut ialah Akalily (2020), Yuhastina (2016), Meor Mohamad Sollehuddin (2016), Wan Zaida (2009), Mohd Zariat (2006; 2008), Ramasamy (2007), Ungku Maimunah (2002; 2009), Mohamad Mokhtar (2002) dan Shamsul Amri (2002). Sorotan kajian mendapati bahawa korpus penyelidikan tentang Pujangga Melayu sehingga kini, rata-rata menyerlahkan tiga kecenderungan yang jelas. Pertama, kecenderungan kajian-kajian ilmiah yang mengkaji Pujangga Melayu dengan menggunakan pendekatan Barat. Hal ini jelas dalam kajian Wan Zaida (2009) yang menerapkan pendekatan kajian budaya yang dicetuskan oleh Chris Barker 
dan Ben Agger. Kedua, kecenderungan kajian-kajian ilmiah yang mengkaji Pujangga Melayu dengan menggunakan pendekatan tempatan. Kecenderungan ini pula dapat dilihat dalam kajian yang diusahakan oleh Mohamad Mokhtar (2002) yang mengaitkan Pujangga Melayu dengan PB, Shamsul Amri (2002) yang mengaitkan Pujangga Melayu dengan soal kemelayuan dan Yuhastina (2016) yang menerapkan kerangka Ranah-Budi. Ketiga, kecenderungan kajian-kajian ilmiah yang mengkaji Pujangga Melayu dengan menerapkan PB. Kecenderungan ini dapat dilihat dalam kajian Ramasamy (2007), Mohd Zariat (2006; 2008), Ungku Maimunah (2002; 2009), Meor Mohamad Sollehuddin (2016) dan Akalily (2020). Daripada pengamatan yang dilakukan, soal pemeragaan novel Pujangga Melayu belum lagi dibahaskan secara kritis dalam kajian-kajian ilmiah sedia ada yang lebih menfokuskan ilmu, pemikiran dan wacana termasuk tema dan persoalan yang dikemukakan, dan bukannya label yang diperagakan terhadap Pujangga Melayu. Jelas bahawa, soal pemahaman serta penerimaan para pengkaji, pengkritik dan sarjana sastera khususnya terhadap istilah-istilah yang telah digunakan dalam pemeragaan novel Pujangga Melayu belum diberikan fokus yang tersendiri. Seperti yang telah dikenal pasti dalam pengamatan sebelum ini, novel persuratan yang dilabelkan pada Pujangga Melayu rata-rata ditakrifkan sebagai novel yang menitikberatkan ilmu, pemikiran dan wacana. Dengan takrifan ini, novel persuratan dikategorikan kepada dua ciri. Ciri pertama ialah pemikiran/wacana sebagai pengisian utamanya manakala ciri kedua pula ialah cerita yang hanya berfungsi sebagai wadah bagi mengutarakan pemikiran/wacana. Perlu ditekankan bahawa takrifan dan ciri-ciri berkenaan hanya digunakan secara konsisten dan eksplisit dalam penerbitan Pujangga Melayu edisi kedua. Jelas di sini bahawa penerbitan sebelum tahun 2017 tidak secara konsisten dan eksplisit memperagakan Pujangga Melayu sebagai novel persuratan sebaliknya menggunakan beberapa istilah lain secara longgar, antaranya seperti "karya persuratan", "novel persuratan" dan "rakaman persuratan".

Hal ini mengundang persoalan kajian tentang adakah kajian-kajian ilmiah yang dilakukan sebelum tahun 2017 telah sedia mengesan kecenderungan Pujangga Melayu sebagai sebuah novel persuratan dengan takrifan serta ciri-ciri yang dikemukakan dalam edisi kedua? Jika tidak, apakah pula kekuatan novel Pujangga Melayu yang telah dikenal pasti oleh kajian-kajian ilmiah sebelum tahun 2017, iaitu sebelum Pujangga Melayu diperagakan secara konsisten dan eksplisit sebagai novel persuratan? Kajian ini berhasrat untuk merungkaikan kedua-dua persoalan tersebut dengan memberikan fokus terhadap kekuatan Pujangga Melayu seperti yang dikenal pasti oleh kajian-kajian ilmiah sebelum tahun 2017. 


\section{Objektif Kajian}

Bertitik tolak daripada permasalahan yang dikemukakan, kajian ini menggariskan dua objektif iaitu menganalisis kajian-kajian ilmiah terhadap novel Pujangga Melayu sebelum tahun 2017 dan merumuskan kekuatan novel Pujangga Melayu berdasarkan hasil dapatan kajian-kajian ilmiah sebelum tahun 2017.

\section{Metodologi dan Bahan Kajian}

Kajian ini menerapkan metodologi penyelidikan yang bersifat kualitatif dengan mengguna pakai pendekatan analisis kandungan. Menurut United States General Accounting Office (1996), analisis kandungan merupakan satu metodologi kajian yang sistematik dan seragam bagi menganalisis serta membuat kesimpulan terhadap maklumat dalam bentuk teks, berpadanan dengan pernyataan, "Here is a formal definition of content analysis: it is a systematic research method for analyzing textual information in a standardized way that allows evaluators to make inferences about that information" (United States General Accounting Office 1996, 6). Sejajar dengan definisi tersebut, Krippendorff (2004, 18) memperakukan analisis kandungan sebagai satu alat saintifik (scientific tool) yang menggariskan enam komponen konseptual yang dapat digunakan dalam analisis bahan kajian, iaitu (1) teks kajian, (2) permasalahan kajian, (3) konteks kajian, (4) pembikinan analisis, (5) kesimpulan dan (6) hujah sokongan (Krippendorff 2004, 29-30). Dengan menerapkan enam komponen ini, teks kajian dapat dianalisis bagi merungkaikan permasalahan yang dibangkitkan dalam satu konteks analisis yang jelas untuk mencapai kesimpulan yang bakal menjawab persoalan kajian. Dalam konteks kajian ini, kesemua enam komponen telah dijelaskan dalam perbincangan sebelum ini.

Merujuk kepada bahan kajian pula, kajian-kajian ilmiah yang mengkaji Pujangga Melayu dibataskan dalam jangka masa sebelum tahun 2017. Kriteria ini sejajar dengan permasalahan kajian yang membangkitkan tentang pentingnya diberikan fokus terhadap soal pemeragaan Pujangga Melayu sebagai novel persuratan dalam penerbitan edisi kedua pada tahun 2017. Berdasarkan kriteria berkenaan dan penelitian kepustakaan, kajian ini berhasil mengenal pasti 10 kajian ilmiah sebelum tahun 2017 yang mengkaji novel Pujangga Melayu. Kesemua kajian ini menjadi bahan kajian yang akan dianalisis hasil-hasil dapatannya bagi merealisasikan kedua-dua objektif dan permasalahan kajian. 


\section{Analisis dan Perbincangan}

Bahagian ini akan menganalisis 10 kajian ilmiah yang dilakukan terhadap Pujangga Melayu sebelum tahun 2017, iaitu sebelum novel tersebut diperagakan secara eksplisit sebagai sebuah novel persuratan. Kajian-kajian ilmiah ini akan dianalisis berdasarkan hasil-hasil dapatan yang sekali gus menyerlahkan kecenderungan dalam memperagakan Pujangga Melayu. Oleh itu dari segi organisasi, bahagian analisis dan perbincangan ini akan disusun mengikut kecenderungan pemeragaan terhadap Pujangga Melayu dan bukan berdasarkan tahun kajian-kajian ilmiah itu diterbitkan.

\section{Pujangga Melayu sebagai "novel wacana"}

Penelitian ini mendapati bahawa terdapat kajian-kajian ilmiah yang cenderung memperagakan Pujangga Melayu sebagai novel wacana. Kecenderungan ini diperlihatkan antaranya dalam projek ilmiah oleh Meor Mohamad Sollehuddin berjudul “Konsep 'Persuratan' dan Konsep 'Sastera' dalam Novel Pujangga Melayu karya Mohd Affandi Hassan" (2016). Projek ilmiah Meor Mohamad Sollehuddin ini tertumpu pada persoalan tentang dua konsep yang diutarakan dalam Pujangga Melayu iaitu "persuratan" dan "sastera". Projek ilmiah beliau memanfaatkan PB sebagai kerangka analisis dengan menerapkan dua alat analisis PB iaitu wacana yang merujuk kepada penghujahan idea-idea secara sistematik dan cerita yang merujuk kepada pengemblengan alat-alat penceritaan seperti watak, plot dan sebagainya. Dengan menerapkan kedua-dua alat analisis berkenaan, projek ilmiah tersebut mengenal pasti strategi pembinaan wacana yang digunakan oleh Mohd Affandi dalam membahaskan tentang konsep persuratan dan sastera. Strategi pertama ialah strategi Pujangga Melayu dalam membina wacana tentang perbezaan tugas antara pengarang dengan sasterawan. Dalam hal ini, Pujangga Melayu membahaskan tentang tugas pengarang dalam menyampaikan ilmu, berpadanan dengan tugas para ulama' dalam tradisi keilmuan Islam. Strategi ini diperkukuh melalui perbandingannya dengan tugas sasterawan yang disamakan dengan tugas penglipur lara dalam tradisi lisan. Strategi kedua pula ialah strategi Pujangga Melayu dalam membina wacana tentang falsafah persuratan yang menjadi pegangan pengarang, iaitu satu falsafah yang mengutamakan akal dan logik berpaksikan taklif iaitu kebertanggungjawaban manusia dengan Allah SWT. Dalam satu makalah oleh Ungku Maimunah, istilah taklif ini dijelaskan sebagai keyakinan kepada Allah SWT sebagai Tuhan yang Esa dan manusia sebagai hamba yang terikat dengan janji azali (Ungku Maimunah 2010, 123). Janji azali inilah yang menuntut agar manusia menjalankan kehidupan di dunia sejajar dengan fitrah kejadiannya, iaitu untuk melakukan kebaikan. Dalam konteks perbincangan 
kajian Meor Mohamad Sollehuddin, pembaca dapat mengatakan bahawa kebaikan dalam kegiatan penulisan disampaikan menerusi falsafah persuratan. Strategi ini diperkukuh melalui perbandingannya dengan falsafah sastera yang menjadi pegangan sasterawan iaitu satu falsafah yang berasaskan emosi dan imaginasi. Strategi ketiga ialah strategi Pujangga Melayu dalam membina wacana tentang takrifan persuratan sebagai kegiatan karang-mengarang untuk menyampaikan ilmu yang benar di sisi Islam. Strategi ini diperkukuh pula melalui perbandingannya dengan takrifan sastera sebagai kegiatan penulisan yang diasaskan pada pandangan peribadi manusia. Seterusnya, strategi keempat ialah strategi Pujangga Melayu dalam membina wacana tentang ciri karya persuratan yang diukur berdasarkan isi kandungannya yang menyampaikan ilmu yang benar. Strategi ini diperkukuh pula melalui perbandingannya dengan ciri karya sastera yang menyampaikan cerita. Dengan pengenalpastian empat strategi tersebut, projek ilmiah Meor menyimpulkan bahawa Pujangga Melayu merupakan sebuah novel yang mengandungi wacana tentang konsep persuratan yang dikontraskan dengan konsep sastera dari segi tugas, falsafah, takrifan dan ciri karya yang dihasilkan. Dengan kata lain, projek ilmiah Meor Mohamad Sollehuddin dengan jelas memperagakan Pujangga Melayu sebagai novel wacana yang mengandungi idea-idea ilmiah yang dibangunkan secara sistematik.

Penting untuk dijelaskan di sini bahawa sebelum projek ilmiah Meor Mohamad Sollehuddin, kajian ilmiah oleh Mohd Zariat yang terbit pada tahun 2006 dan 2008, telah terlebih dahulu melabelkan Pujangga Melayu sebagai novel wacana. Dalam artikel beliau berjudul "Wacana Seksualiti Insan dalam Novel Pujangga Melayu oleh Mohd Affandi Hassan" (2006), Mohd Zariat memfokuskan terhadap idea wacana seksualiti insan dalam novel Pujangga Melayu. Maksud wacana seksualiti insan ialah idea-idea berkaitan hal kejantinaan manusia yang dibangunkan secara sistematik dan dinilai berasaskan kerangka Islam. Mohd Zariat antara lain menjelaskan bahawa soal seksualiti dalam Pujangga Melayu wajar dilihat dalam konteks penyampaian ilmu yang menjadi tuntutan PB. Justeru, bagi berlaku adil terhadap novel Pujangga Melayu, kajian Mohd Zariat $(2006,132)$ menerapkan PB sebagai kerangka analisis. Penerapan PB membolehkan Mohd Zariat untuk membezakan antara wacana dengan cerita iaitu dua komponen utama yang didapatinya terkandung dalam Pujangga Melayu. Dalam konteks perbezaan antara kedua-dua komponen ini, wacana dikenal pasti sebagai komponen yang bukan sahaja dominan, malah menonjolkan ciriciri ilmiah dalam novel Pujangga Melayu (Mohd Zariat 2006, 132) manakala cerita dalam Pujangga Melayu pula merujuk kepada alat-alat penceritaan yang dimanipulasi bagi menampung wacana (Mohd Zariat 2006, 132). Makalah Ungku Maimunah (2012b, 1215-1216) umpamanya turut menegaskan bahawa komponen ilmu dan cerita hadir dari aspek kedudukan, fungsi dan 
bentuk yang berbeza, selain meletakkan ilmu pada hierarki yang lebih tinggi berbanding cerita, sekali gus menyerlahkan kepentingan wacana. Berasaskan pengenalpastian komponen wacana, analisis Mohd Zariat $(2006,144)$ mengenal pasti tiga aspek tentang seksualiti insan yang dibahaskan dalam Pujangga Melayu, iaitu "hakikat naluri kejantinaan insan", "wacana cinta sesama insan" dan "wacana poligami Islam". Ketiga-tiga aspek itu dikupas berdasarkan kerangka taklif yang bertunjangkan kebertanggungjawaban manusia kepada penciptanya iaitu Allah SWT. Kajian Mohd Zariat (2006, 157-158) menyimpulkan bahawa persoalan seksualiti dalam Pujangga Melayu dibahaskan secara ilmiah melalui komponen wacana yang dihadirkan dalam sebuah novel. Kajian Mohd Zariat ini jelas memperagakan Pujangga Melayu sebagai novel wacana yang membahaskan persoalan seksualiti secara ilmiah.

Berbeza dengan artikel tersebut yang tertumpu kepada seksualiti, Mohd Zariat turut melanjutkan penelitiannya terhadap Pujangga Melayu dengan fokus kepada aspek wacana dan cerita itu sendiri. Dalam artikel bertajuk "Wacana dan Cerita dalam Novel Pujangga Melayu karya Mohd Affandi Hassan" (2008), Mohd Zariat menganalisis novel Pujangga Melayu dengan membangkitkan permasalahan tentang fungsi karya kreatif. Permasalahan ini diperkukuh dengan aspirasi Mohd Affandi sendiri yang menegaskan bahawa karya-karya kreatif beliau berfungsi untuk menyampaikan ilmu. Justeru, artikel Mohd Zariat diusahakan bagi menguji keupayaan Mohd Affandi dalam merealisasikan aspirasi tersebut. Dengan menerapkan PB, analisis Mohd Zariat tertumpu pada usaha untuk mengenal pasti dan seterusnya membezakan antara dua bentuk isian, iaitu "isian wacana" dengan "isian cerita". Isian wacana dikonsepkan sebagai idea-idea yang dihujahkan secara sistematik antaranya melalui pengutaraan, pengupasan, pentafsiran dan perdebatan idea. Hal ini berbeza dengan isian cerita yang dikonsepkan sebagai alat-alat penceritaan seperti watak dan peristiwa yang digembleng bagi membangunkan sebuah cerita. Kedua-dua konsep ini diketengahkan sebagai alat analisis yang secara khusus dikonsepsikan oleh PB bagi mengenal pasti fungsi karya kreatif seperti novel. Kedua-dua konsep ini juga dikatakan bertentangan dengan pemahaman konvensional dalam sastera moden yang menangani cerita sebagai ilmu. Selain itu, perkara yang turut diterapkan ialah konsep "paksi naratif" dan "ruang naratif" yang dicetuskan oleh Ungku Maimunah. Kedua-dua konsep ini dapat digunakan dalam mengenal pasti jenis isian yang secara dominan mengisi Pujangga Melayu, sama ada isian wacana atau isian cerita. Analisis Mohd Zariat antaranya berhasil dalam mengenal pasti taklif sebagai paksi naratif Pujangga Melayu yang ditegakkan melalui soal cita-cita dan perjuangan hidup seorang sarjana Melayu dari usia kanak-kanak hingga dewasa. Dengan paksi ini, Pujangga Melayu menyediakan ruang naratifnya untuk diisi dengan kedua-dua bentuk isian, iaitu isian wacana dan isian cerita. Analisis Mohd Zariat mengenal 
pasti isian cerita seperti watak dan peristiwa dalam ruang naratif Pujangga Melayu. Antara yang dibangkitkan oleh Mohd Zariat ialah penampilan watak protagonisnya, Awang sebagai sarjana yang memiliki kebijaksanaan akal, sekali gus membolehkan kehadiran hujah-hujah ilmiah. Begitu juga dengan kehadiran watak-watak sampingan yang sebahagiannya ditampilkan dengan perwatakan yang rajin bertanya manakala sebahagian lagi mampu menyanggah pandangan protagonis. Kedua-dua jenis perwatakan ini menurut Mohd Zariat menjadikan watak-watak sampingan dalam Pujangga Melayu berfungsi dalam menyemarakkan lagi hujah-hujah ilmiah yang disampaikan melalui protagonisnya dan sekali gus memperkaya isian wacana dalam ruang naratif Pujangga Melayu, selain pemilihan peristiwa yang menurut Mohd Zariat banyak didasarkan pada keperluan protagonis dalam menyampaikan hujah-hujahnya. Umpamanya, peristiwa-peristiwa yang dipilih sebahagian besarnya bersifat keilmuan seperti majlis usrah, diskusi, forum dan seminar yang dengan mudah diisi dengan isian wacana. Hal yang sama penting ialah kerangka taklif yang didapati mendasari hujah-hujah yang menjadi isian wacana. Dengan kerangka taklif, ruang naratif Pujangga Melayu diisi dengan hujah-hujah berkaitan epistemologi ilmu, hakikat qalam, serta konsep style dan kreativiti menurut Islam (Mohd Zariat 2008, 196). Semua konsep yang berteraskan taklif itu kemudiannya membentuk satu wacana tentang falsafah persuratan yang dibangunkan melalui pengutaraan idea serta perbahasan ilmiah (Mohd Zariat 2008, 197). Dalam konteks ini, analisis Mohd Zariat mengenal pasti bahawa isian wacana mengisi secara dominan ruang naratif Pujangga Melayu (Mohd Zariat 2008, 199). Kesimpulan ini menyerlahkan kecenderungan artikel Mohd Zariat dalam memperagakan Pujangga Melayu sebagai sebuah novel wacana yang sarat dengan strategi penggemblengan idea yang dihujahkan secara sistematik.

Pemerihalan yang sama turut ketara dalam kertas kerja yang dibentangkan oleh Shamsul Amri berjudul "Pujangga Melayu, Pujangga Idaman: Problematika Identiti Melayu-Muslim Malaysia" (2002). Meskipun kertas kerja beliau tidak secara eksplisit menamakan Pujangga Melayu sebagai novel wacana, namun kekuatan-kekuatan novel yang ditonjolkan jelas mengarah kepada perakuan tersebut. Sebagai seorang ahli antropologi, Shamsul Amri dilihat cenderung mendekati Pujangga Melayu sebagai manifestasi pemikiran seorang pengarang Melayu dan beragama Islam, dan justeru lebih tertarik kepada aspek "kemelayuan" (Malayness) yang terjelma. Dengan fokus ini, analisis beliau dipandu oleh empat kata kunci iaitu "konseptual", "pemerihalan dan penghuraian", "analitikal" dan "kepengarangan". Dari segi konseptual, analisis Shamsul Amri mengenal pasti bahawa pemikiran Mohd Affandi tentang ukuran identiti Melayu-Muslim adalah didasarkan pada ajaran Islam. Menurut Shamsul Amri, hal ini antaranya jelas pada contoh novel yang mengupas tentang ukuran 
identiti Melayu-Muslim tersebut dari segi kegiatan sastera Melayu. Shamsul Amri $(2002,4)$ menyifatkan bahawa penjelasan mengenai falsafah sastera dengan falsafah persuratan dalam Pujangga Melayu dibezakan menerusi Islamisasi beberapa konsep fundamental dalam kegiatan berkenaan. Dari segi pemerihalan dan penghuraian, Shamsul Amri $(2002,5)$ mengesan kecenderungan Mohd Affandi yang memasukkan banyak kupasan mengenai wacana Islam, iaitu "peri pentingnya prinsip Islam, atau lemahnya amalan bercorak Islam dalam pembinaan identiti Melayu-Muslim di Malaysia”. Dari segi analitikal pula, analisis Shamsul Amri mengenal pastiMohd Affandi sebagai seorang pengarang bersifat strukturalis yang menuntut struktur "authority-defined", iaitu suatu pendekatan yang memperakukan perbezaan martabat manusia yang ditakrifkan oleh Islam. Dari segi kepengarangan pula, Shamsul Amri berpendapat bahawa Pujangga Melayu memperlihatkan kontradiksi pendirian Mohd Affandi berkenaan kedudukan pengarang yang bertentangan dengan sasterawan. Hal ini kerana menurut Shamsul Amri, Pujangga Melayu meletakkan kedudukan pengarang sebagai lebih berautoriti kerana menyampaikan ilmu manakala sasterawan pula dipandang rendah kerana menyampaikan khayalan. Pendirian ini jelas memperlihatkan pertentangan kepada Shamsul Amri kerana menurutnya, Pujangga Melayu sendiri ialah novel sastera, seperti dalam pernyataannya, "Kalaulah sasterawan begitu terhina kedudukannya dari segi Islam kerana, menurut Mohd Affandi, 'mereka adalah makhluk khayal tidak berilmu', apa jadi pada Mohd Affandi dan karya sasteranya berjudul Pujangga Melayu (1997) yang saya anggap sebagai suatu karya sastera yang luar biasa?" (Shamsul 2002, 6). Dalam konteks ini, dapatlah dikatakan keluarbiasaan Pujangga Melayu adalah pada kejayaan Mohd Affandi membicarakan problematika dalam pembentukan identiti Melayu-Muslim di Malaysia, sebagaimana yang dinyatakan oleh Shamsul Amri sendiri, "Saya ingin merumuskan bahawa MAH [Mohd Affandi] telah berjaya membicarakan problematika dalam pembentukan identiti MelayuMuslim di Malaysia melalui karya sasteranya ini" (Shamsul 2002, 7). Justeru, dapat juga dikatakan bahawa problematika ini cenderung terhadap maksud wacana, sekaligus mengelompokkannya dalam kajian yang memperakukan Pujangga Melayu sebagai novel wacana.

\section{Pujangga Melayu sebagai "novel ilmu"}

Penelitian ini mendapati bahawa terdapat kajian-kajian ilmiah yang cenderung memperagakan Pujangga Melayu sebagai novel ilmu. Kecenderungan ini diperlihatkan antaranya dalam tesis sarjana oleh Wan Zaida berjudul "Pemikiran dalam Novel Mohd Affandi Hassan: Analisis dari Sudut Kajian Budaya" (2009). Dengan menerapkan pendekatan kajian budaya, kajian Wan Zaida meneliti soal kebudayaan dalam lima buah novel Mohd Affandi iaitu Aligupit dan empat 
novel yang terangkum dalam Pujangga Melayu. Pemilihan pendekatan kajian budaya diasaskan pada keyakinan Wan Zaida bahawa karya sastera berperanan sebagai dokumentasi sosial (rakaman peristiwa) yang merakamkan ketamadunan sesebuah bangsa (Wan Zaida 2009, 60). Wan Zaida (2009, 143) turut membangkitkan hipotesisnya bahawa kepengarangan Mohd Affandi didorong oleh keinginan beliau untuk menonjolkan kekuatan jati diri bangsa Melayu yang didasarkan pada budaya ilmu. Dalam konteks ini, aspek yang jelas diamati ialah aspek cerita khususnya watak-watak dan peristiwa-peristiwa penting yang dipaparkan dalam Pujangga Melayu. Hal ini umpamanya jelas apabila Wan Zaida dalam beberapa bahagian kajiannya menegaskan kehadiran watak berilmu dalam novel Pujangga Melayu, terutamanya protagonis novel iaitu Awang. Hal yang tidak kurang pentingnya adalah kehadiran isteri-isteri Awang yang juga ditampilkan sebagai watak wanita berilmu dan memainkan peranan penting dalam menentukan kebudayaan ilmu menerusi institusi kekeluargaan (Wan Zaida 2009, 223). Selain daripada kehadiran watak-watak berilmu ini bagi memanifestasikan kebudayaan ilmu, analisis Wan Zaida turut mengenal pasti aspek peristiwa ditampilkan bagi tujuan yang sama (Wan Zaida 2009, 189). Justeru, Wan Zaida menyimpulkan bahawa kajiannya terhadap novel Pujangga Melayu dengan menerapkan pendekatan kajian budaya berhasil dalam menemukan ilmu sebagai aspek teras dalam kebudayaan, seperti kenyataan beliau, "Bacaan terhadap lima buah novelnya (novel Mohd Affandi) memperlihatkan kesatuan idea dan pemikiran tentang ilmu sebagai asas pembinaan budaya" (Wan Zaida 2009, 333). Jelas di sini bahawa kajian Wan Zaida ini merumuskan Pujangga Melayu sebagai novel ilmu yang mengutarakan persoalan berkaitan jati diri Melayu.

Selanjutnya, pemeragaan Pujangga Melayu sebagai novel ilmu turut ketara dalam tesis kedoktoran Yuhastina yang berjudul "Ranah-Budi dalam Novel Indonesia dan Malaysia" (2016). Kajian Yuhastina ini bertujuan menguji sebuah kerangka binaannya sendiri ("Ranah-Budi"), yang merangkumi tiga ranah iaitu "ranah sumber daya" yang bermaksud aspek kepercayaan dan kemanusiaan, "ranah modal" yang bermaksud aspek ekonomi dan kemasyarakatan, dan "ranah wacana pengetahuan" yang bermaksud aspek keilmiahan (Yuhastina 2016, 8-9). Secara keseluruhannya, "ranah budi" bertujuan untuk meneliti gabungan ketiga-tiga ranah bagi membentuk agenda kemasyarakatan dalam novel-novel Indonesia dan Malaysia (Yuhastina 2016, 3). Merujuk kepada Pujangga Melayu, kajian Yuhastina antaranya membangkitkan kepentingan ceritanya yang berpusat pada watak Awang yang dididik dengan ajaran Islam sejak kecil, dan seterusnya membentuk nilai yang baik, atau apa yang disebutnya sebagai "normatifiti" dalam konteks kerangka Tauhid (Yuhastina 2016, 53). "Normatifiti" yang dipilih oleh Mohd Affandi dalam Pujangga Melayu telah menzahirkan pemikiran watak Awang yang dipayungi oleh konsep-konsep penting dalam ajaran Islam. Justeru, 
kajian Yuhastina berpandangan bahawa watak Awang yang mendominasi hampir keseluruhan novel Pujangga Melayu menjadi manifestasi kerangka tauhid. Seterusnya, kajian Yuhastina juga mendapati bahawa ranah sumber daya dan ranah modal bergabung dan dimanifestasikan dalam dialog Awang dengan watakwatak sampingan novel, sekali gus telah mendorong ke arah penzahiran ranah wacana pengetahuan. Penting dijelaskan bahawa kajian Yuhastina menyenaraikan ranah wacana pengetahuan kepada tiga jenis wacana. Pertama, "wacana pengetahuan normatif" yang merupakan pengetahuan mengenai nilai yang baik. Kedua, "wacana pengetahuan kritikal" yang merupakan perbahasan antara dua perkara yang bertentangan dalam kalangan watak-watak. Ketiga, "wacana pengetahuan strategikal" yang merupakan penghujahan yang disusun oleh novel bagi menonjolkan satu perkara yang menjadi keutamaan. Analisis Yuhastina mendapati Pujangga Melayu mengandungi wacana pengetahuan normatif ketika menonjolkan watak Awang menerima pendidikan Islam dan mengamalkannya dalam kehidupan. Selain itu, Pujangga Melayu turut didapati mengandungi wacana pengetahuan kritikal yang dimanifestasikan pada kritikan-kritikan terhadap aspek-aspek yang bertentangan dengan wacana pengetahuan normatif. Hal yang lebih penting lagi menurut Yuhastina ialah wacana pengetahuan kritikal itu kemudiannya disampaikan dalam Pujangga Melayu melalui wacana pengetahuan strategikal, sebagaimana yang jelas sewaktu novel menstrategikan Awang sebagai tokoh yang memiliki kedudukan dan kuasa yang tinggi dalam hierarki sosial (iaitu sebagai seorang profesor) ketika menyampaikan wacana berkenaan persuratan dan sastera. Yuhastina turut memberi perhatian terhadap strategi novel yang mempertentangkan dua perkara, misalnya persuratan dan sastera (Yuhastina 2016, 262). Yushatina menyimpulkan bahawa Pujangga Melayu berhasil dalam mengintegrasikan penggunaan ranah sumber daya dengan ranah modal dalam usaha menghasilkan tiga ranah wacana pengetahuan atau kehadiran ilmu dalam Pujangga Melayu (Yuhastina 2016, 275). Justeru, dapat dikatakan bahawa tesis kedoktoran Yuhastina cenderung memperagakan Pujangga Melayu sebagai sebuah novel ilmu.

Seterusnya, kecenderungan yang sama juga kelihatan dalam kertas kerja Mohamad Mokhtar berjudul "Pujangga Melayu Mohd Affandi Hassan: Satu Interpretasi Pemikiran Pengarang" (2002). Meskipun tidak menyimpulkannya secara eksplisit, namun jelas pada pemilihan topik-topik yang menjadi fokus perbincangannya bahawa kertas kerja Mohamad Mokhtar tidak dapat menafikan kekuatan Pujangga Melayu dalam menyampaikan ilmu. Kertas kerja beliau dibahagikan kepada tiga subjudul iaitu "Teori Persuratan Baru", "Kritikan" dan "Falsafah", yang kesemuanya merupakan topik-topik integral dalam gagasan PB yang dianggap telah melahirkan Pujangga Melayu. Hakikat ini diakui sendiri oleh Mokhtar yang menganggap bahawa Pujangga Melayu merupakan medan 
penyampaian berkenaan PB (Mohamad Mokhtar 2002, 2). Di bawah subjudul "Teori Persuratan Baru", analisis Mokhtar antaranya membangkitkan tentang perbahasan ilmiah mengenai falsafah serta konsep penting dalam PB seperti "falsafah persuratan" yang dipertentangkan dengan "falsafah sastera", konsep pengarang yang dibandingkan dengan sasterawan, novel persuratan yang dibezakan daripada novel sastera, selain konsep style dan stylisation of ideas, yang kesemuanya ini dibahaskan dalam Pujangga Melayu. Di bawah subjudul "Kritikan" pula, analisis Mohamad Mokhtar mengenal pasti adanya sejumlah kritikan dalam Pujangga Melayu seperti kebebasan akhbar, kemuliaan kerjaya wartawan dan ahli sukan, kebersihan sistem politik dan ekonomi, serta keilmiahan para sarjana di institusi pendidikan. Antara perkara yang paling mendapat sorotan ialah kritikan kepada golongan sasterawan yang menurut beliau mengambil tempat agak lumayan dalam Pujangga Melayu. Di bawah subjudul "Falsafah", analisis beliau mengenal pasti adanya falsafah yang diselitkan sebagai panduan kepada pembaca seperti falsafah kesabaran, kehidupan dan tugas guru. Semakin memperteguhkan kesimpulan bahawa kertas kerja beliau sememangnya memperakukan Pujangga Melayu sebagai novel ilmu dapat diteliti pada kenyataan beliau sendiri:

Ternyata novel (Pujangga Melayu) ini lebih banyak berkisar kepada ilmu. Penjelasan ilmu oleh ayah Awang pada awal cerita. Kemudian Awang melanjutkan pelajaran ke luar negeri kerana ingin menuntut ilmu. Seminar-seminar yang diadakan bertujuan untuk menyebarkan ilmu. Dan usaha untuk menubuhkan Universiti Islam Darulnaim juga kerana $i l m u . .$. Jelas bahawa novel ini lebih banyak berkisarkan ilmu. Malah membaca novel ini juga banyak ilmu yang ingin disampaikan oleh pengarang [penekanan penulis dalam tulisan berhuruf condong]. (Mohamad Mokhtar 2002, 2)

Kenyataan di atas dengan jelas menyerlahkan kecenderungan beliau dalam memperakukan Pujangga Melayu sebagai sebuah novel ilmu.

Akhir sekali, kecenderungan yang memperakukan Pujangga Melayu sebagai novel ilmu turut diperlihatkan dalam buku Ungku Maimunah berjudul Dinamika Pemikiran Sastera Melayu (2009). Dalam bab terakhir, Ungku Maimunah menganalisis Pujangga Melayu dari aspek bentuknya sebagai sebuah "novel realis" iaitu bentuk yang mendapat sambutan yang luas di Barat. Secara umum, dapatlah dikatakan bahawa novel realis merupakan bentuk novel yang menitikberatkan paparan secara realistik. Kajian Ungku Maimunah (2009, 113) antaranya menyatakan bahawa perbezaan Pujangga Melayu dengan novel realis terletak pada isi kandungan novel itu sendiri. Berbeza dengan novel realis yang didasarkan pemeriannya kepada fizikal dunia sebenar, Pujangga 
Melayu mengandungi wacana yang dapat membahaskan ilmu secara substantif. Pada dasarnya, ilmu yang dimaksudkan oleh beliau ini merujuk kepada "ilmu yang benar" yang dapat mengajar manusia tentang hakikat kebenaran di sisi Islam (Ungku Maimunah 2009, 123-124). Dalam satu makalahnya yang lain, beliau turut merujuk "ilmu yang benar" sebagai ilmu yang bersumberkan wahyu dan dapat mengenalkan manusia kepada Allah, selain menyifatkan sesuatu itu bukanlah ilmu yang benar jika tidak dapat mencapai maksud yang demikian (Ungku Maimunah 2012a, 541). Dengan pengertian ilmu ini, beliau menegaskan bahawa wacana dibina dalam Pujangga Melayu dengan tujuan menyampaikan ilmu. Dalam konteks penyampaikan ilmu itu sendiri, Pujangga Melayu menurut Ungku Maimunah $(2009,114)$ menghadirkan wacana pada banyak bahagian novel, selain menggunakan cara berhujah yang bersifat utuh-kendiri (self-sufficient). Kedua-dua cara ini, menurut beliau, menjadikan ilmu yang disampaikan dalam Pujangga Melayu bersifat substantif dan kumulatif dengan hujah-hujah kukuh yang disertakan dengan taburan contoh sebagai pembuktian (Ungku Maimunah 2009, 114).

Seterusnya menurut Ungku Maimunah, pembinaan wacana dengan cara sedemikian adalah konsisten sepanjang novel, dan strategi ini telah menjadikan wacana dalam Pujangga Melayu lebih dominan daripada cerita. Hal ini menjadikan Pujangga Melayu sebagai sebuah novel yang berbeza dengan novel realis yang menitikberatkan paparan secara realistik (Ungku Maimunah 2009, 123-124). Ungku menegaskan bahawa meskipun Pujangga Melayu sebagai sebuah novel tetap memanfaatkan alat-alat penceritaan seperti watak dan peristiwa, namun pemanfaatannya itu tidak pula akur terhadap falsafah realisme yang menuntut kepada pemerian kejadian dalam kehidupan secara rinci dan realistik (Ungku Maimunah 2009, 125). Sebaliknya, Pujangga Melayu memanfaatkan alat-alat penceritaan dengan motif penulisannya yang jelas iaitu membolehkan wacana hadir dalam novel bagi tujuan menyampaikan "ilmu yang benar". Dengan kata lain, dalam Pujangga Melayu, realisme serta bentuk "novel realis" telah ditundukkan bagi merealisasikan matlamat PB iaitu menyampaikan "ilmu yang benar". Dalam konteks ini, Ungku Maimunah secara eksplisit menampilkan Pujangga Melayu sebagai novel ilmu, sebagaimana yang disimpulkannya, "Tegasnya, melalui Pujangga [Pujangga Melayu], realisme dan novel dimurnikan sebagai gandingan yang menjulang aspirasi PB. Oleh sebab itulah Pujangga [Pujangga Melayu] adalah novel ilmu." [penekanan penulis dalam tulisan berhuruf condong] (Ungku Maimunah 2009, 125). 


\section{Pujangga Melayu sebagai "karya persuratan"}

Akhir sekali, penelitian ini turut mendapati bahawa terdapat kajian-kajian ilmiah yang memperagakan Pujangga Melayu sebagai karya persuratan. Kecenderungan ini diperlihatkan antaranya dalam tesis sarjana oleh Ramasamy berjudul "Pujangga Melayu: Dari Sudut Pendekatan Persuratan Baru" (2007) yang memperagakan Pujangga Melayu sebagai sebuah karya persuratan. Tesis ini meneliti aspek pemikiran dan style dalam Pujangga Melayu berdasarkan kerangka PB. Sebagai sebuah karya persuratan, kajian Ramasamy antaranya membangkitkan kekuatan Pujangga Melayu dalam menggarap kerangka Tauhid dan Taklif (Ramasamy 2007, 181-182). Selanjutnya, kajian Ramasamy mengenal pasti tiga pemikiran pokok yang mengisi Pujangga Melayu. Pertama ialah pemikiran tentang "peralihan falsafah sastera kepada falsafah persuratan". Antaranya, Ramasamy membangkitkan perbincangan tentang "kebebasan" berkarya dalam falsafah sastera yang tidak terdapat dalam falsafah persuratan. Ramasamy menghujahkan falsafah persuratan sebagai penghasilan karya berpandukan "kalam", selain merupakan seni persuratan yang menuntut pengarang berfikir dan mengarang (Ramasamy 2007, 74). Terlepas daripada perbincangan di atas, Ramasamy menegaskan bahawa falsafah sastera dalam Pujangga Melayu wajar diteliti dengan mendalam kerana mengandungi perbahasan mengenai kekeliruan nilai yang menjadi amalan sasterawan. Ramasamy menyifatkan pemikiran ini sebagai pemikiran yang bermakna dan telah ditulis oleh Mohd Affandi secara mendalam dengan berpaksikan ilmu yang benar. Kedua ialah pemikiran mengenai "perkahwinan dan poligami Islam". Pemikiran ini dibangunkan melalui idea-idea berkaitan kehormatan wanita, tanggungjawab lelaki, soal cinta, serta hikmah dan fungsi poligami, yang kesemuanya dibincangkan berasaskan konsep "ilmu yang benar" di sisi Islam. Ramasamy berpendapat bahawa pemikiran tersebut dibangunkan secara sistematik dalam Pujangga Melayu dengan menjadikan soal kehormatan wanita sebagai asas penghujahan (soal dasar). Soal kehormatan wanita ini kemudiannya dikembangkan pula dengan soal tanggungjawab lelaki sebagai pembimbing dan ketua keluarga. Begitu juga soal poligami yang dihujahkan dalam Pujangga Melayu mengikut kerangka tauhid dan taklif, sekali gus memperlihatkan hikmah dan fungsi poligami yang praktikal (Ramasamy 2007, 101). Ketiga ialah pemikiran mengenai "pentadbiran dan kepimpinan Melayu". Pemikiran ini dihujahkan melalui pertembungan dua perspektif, iaitu perspektif watak Awang yang menggagaskan pemikirannya tentang pentadbiran dan kepimpinan berasaskan tauhid dan taklif melalui tulisan-tulisan akademiknya, dengan perspektif watak Bakhtiar yang mengejar keuntungan melalui penglibatannya dalam politik. Di satu pihak, analisis Ramasamy mendapati kedudukan Awang yang sedemikian telah meletakkan Awang sebagai watak berilmu (Ramasamy 2007, 118). Di satu 
pihak lagi, analisis Ramasamy mendapati kedudukan Bakhtiar yang bertentangan dengan Awang, telah meletakkan Bakhtiar sebagai watak yang keliru dan cetek ilmu (Ramasamy 2007, 111). Merujuk kepada tiga pemikiran di atas, kajian beliau menyimpulkan bahawa pemikiran-pemikiran tersebut yang mendominasi Pujangga Melayu telah digarap dengan kemas, selaras dengan konsep "ilmu yang benar" di sisi Islam (Ramasamy 2007, 125).

Seterusnya, kajian Ramasamy turut meneliti aspek style dalam Pujangga Melayu yang menurutnya terserlah melalui penggunaan bentuk khutbah, syair, sajak, cerita pendek, cerita berbingkai, kutipan panjang dan esei. Kajian Ramasamy turut menyebut tentang konsep stylization of ideas atau "siratan makna", yang difahaminya sebagai sejenis kemahiran mengarang yang bersifat "intelektual" (Ramasamy 2007, 127). Dengan pemahaman ini, kajian Ramasamy turut mengesan style penulisan Pujangga Melayu yang menurutnya masih menghadirkan cerita, tetapi memanfaatkan cerita untuk menyampaikan ilmu (Ramasamy 2007, 180). Berdasarkan sorotan di atas, adalah jelas bahawa pada pemahaman Ramasamy, terdapat dua aspek yang menjadi kekuatan Pujangga Melayu iaitu pemikiran dan gaya penulisan. Kedua-dua aspek ini juga dianggap oleh Ramasamy sebagai ciri utama sebuah karya persuratan, sebagaimana yang disimpulkannya:

Menerusi penerapan kerangka PB, kajian memperlihatkan dua aspek penting kajian ini iaitu pemikiran dan "style" penulisan yang didasari PB telah berjaya melakukan dua perkara dalam satu usaha iaitu untuk menghasilkan sebuah karya persuratan dan juga dalam novel diwajarkan anjuran usaha mendukung pendekatan PB itu sendiri seolaholah menggunakan formula "dua dalam satu" atau dengan pemahaman "gabungan kandungan yang luhur dengan gaya persembahan yang luhur" sebagai sebuah seni Islam secara indah dan bermakna [penekanan penulis dalam tulisan berhuruf condong]. (Ramasamy 2007, 184)

Kesimpulan ini jelas menyerlahkan kecenderungan kajian Ramasamy dalam memperagakan Pujangga Melayu sebagai sebuah karya persuratan.

Akhir sekali dan tidak kurang pentingnya, kecenderungan melabelkan Pujangga Melayu sebagai karya persuratan ini juga diperlihatkan dalam artikel Ungku Maimunah bertajuk "Bagaimanakah Pujangga Melayu Harus Ditafsirkan?" (2002). Antara perkara pokok yang ditekankan dalam artikel Ungku Maimunah ini ialah soal kehadiran Pujangga Melayu sebagai "terjemahan konkrit PB dalam bentuk kreatif" (istilah Ungku Maimunah). Dengan penekanan ini, analisis beliau terarah kepada usaha untuk mengaitkan isi kandungan Pujangga Melayu dengan idea-idea pokok PB. Hal ini jelas apabila bahagian awal artikel berusaha menjelaskan tentang $\mathrm{PB}$ yang mengutamakan ilmu, sebagaimana yang 
sedia dihujahkan oleh Mohd Affandi sendiri dalam tulisan-tulisan ilmiahnya (Ungku Maimunah 2002, 37). Menurut Ungku Maimunah, kedudukan Pujangga Melayu sebagai "terjemahan konkrit PB dalam bentuk kreatif" jelas apabila hujah-hujah yang diucapkan melalui dialog oleh watak-watak dalam Pujangga Melayu khususnya protagonisnya Awang, adalah seiring dengan idea-idea yang dibahaskan oleh Mohd Affandi dalam tulisan-tulisan ilmiah beliau (Ungku Maimunah 2002, 37).

Lebih menarik lagi apabila artikel beliau menghadirkan subjudul bertajuk "Pujangga Melayu Sebagai Karya Persuratan". Di bawah subjudul ini, Ungku Maimunah menjelaskan beberapa ciri utama Pujangga Melayu yang diajukan sebagai sebuah karya persuratan. Antaranya ialah "kehadiran ilmu dan penyelapan cerita". Merujuk kepada ciri ini, Pujangga Melayu menurut beliau membincangkan dua konsep pokok iaitu sasterawan dan persuratan, yang dibahaskan secara ilmiah dan analitikal, lengkap dengan penjelasan dari segi etimologi, falsafah dan praktisnya. Dengan itu, kehadiran ilmu dalam Pujangga Melayu ditandai dengan perbahasan ilmiah mengenai dua konsep pokok tersebut. Tidak kurang penting apabila perbahasan ilmiah mengenai dua konsep pokok itu ditempatkan pula dalam cerita yang akur terhadap tuntutan ilmu itu sendiri. Umpamanya, watak protagonis yang dipilih merupakan seorang pengarang yang berwibawa dengan penguasaan ilmunya yang mendalam, sehingga mampu menghujahkan dua konsep pokok yang dikemukakan Pujangga Melayu (Ungku Maimunah 2002, 239). Dalam konteks inilah, beliau memperkukuhkan dakwaannya sendiri bahawa Pujangga Melayu merupakan "terjemahan konkrit PB dalam bentuk kreatif" seperti yang telah dinyatakan lebih awal. Ciri lain yang turut dibangkitkan ialah peminggiran Pujangga Melayu terhadap mimesis atau peniruan iaitu satu konsep yang dirayakan dalam penulisan fiksyen moden. Analisis Ungku Maimunah mendapati bahawa kehadiran watak-watak dalam Pujangga Melayu tidak ditekankan dengan aspek emosi serta aksi, sebaliknya ditampilkan dengan idea-idea ilmiah untuk dibahaskan. Begitu juga kehadiran peristiwa dan babak yang tidak diperikan secara dramatik dan grafik. Jelas bahawa sebagai karya persuratan, Pujangga Melayu menurut Ungku Maimunah mengutamakan ilmu yang benar di sisi Islam yang falsafah serta epistemologinya itu diasaskan pada kerangka tauhid, sebagaimana yang disimpulkan oleh Ungku Maimunah:

Novel ini beroperasi kepada pelbagai tahap membina dan mengumpul makna daripada pelbagai sumber dalam novel, memantapkan idea melalui proses kukuh memperkukuh guna memperakukan satu citra pengarang yang boleh dibanggakan. Mendasari citra ini, dan jelas kelihatan sama ada melalui ide ataupun cara penyampaian, ialah kehadiran paksi falsafah tauhid sebagai kerangka yang kaya, ilmiah, 
relevan dan dapat dipraktikkan dengan jayanya. (Ungku Maimunah 2002, 42)

\section{Rumusan}

Analisis terhadap dapatan kajian-kajian ilmiah sebelum tahun 2017 berhasil dalam mengenal pasti beberapa label yang diperagakan terhadap novel Pujangga Melayu. Antaranya ialah "novel wacana", "novel ilmu" dan "karya persuratan". Merujuk kepada label "novel wacana", analisis mendapati terdapat kajiankajian ilmiah yang memperagakan Pujangga Melayu sebagai sebuah novel yang mengandungi idea-idea ilmiah yang dibangunkan secara sistematik, termasuk sarat dengan strategi penggemblengan idea yang dihujahkan secara sistematik. Dengan pengertian ini, kajian Mohd Zariat (2006; 2008) memperakukan adanya wacana ilmu dan wacana berkaitan seksualiti yang dibangunkan berasaskan kerangka Islam. Begitu juga kajian Meor Mohamad Sollehuddin (2016) yang mengenal pasti adanya wacana berkaitan konsep sastera dan persuratan. Kajian Shamsul Amri (2002) memperakukan Pujangga Melayu sebagai sebuah novel yang menampilkan wacana jati diri kemelayuan (Malayness).

Merujuk kepada label "novel ilmu" pula, analisis mendapati terdapat kajiankajian ilmiah yang menampilkan Pujangga Melayu sebagai sebuah novel yang menyampaikan ilmu, secara khusus "ilmu yang benar" menurut Islam yang menjadi pegangan PB. Meskipun turut menyebut tentang kehadiran wacana dalam Pujangga Melayu, namun kajian Ungku Maimunah (2009) umpamanya cenderung menganggap bahawa ilmu menjadi matlamat akhir dalam pembinaan wacana. Demikian juga kajian Yuhastina (2016) yang memperakukan kekuatan Pujangga Melayu dalam mengintegrasikan ranah sumber daya dengan ranah modal sehingga menghasilkan tiga ranah wacana pengetahuan yang diasaskan pada kerangka tauhid dan taklif. Kajian Mohamad Mokhtar (2002) pula membangkitkan soal adanya perbahasan ilmiah tentang falsafah serta konsep penting PB termasuk kritikan-kritikan yang kritis. Malah, garapan cerita dalam Pujangga Melayu juga secara keseluruhannya dianggap berlegar tentang persoalan ilmu. Begitu juga kajian Wan Zaida mengenal pasti apa yang diungkapkannya sebagai pemikiran tentang persoalan-persoalan pokok berkaitan jati diri Melayu. Penting ditekankan ialah dapatan Wan Zaida (2009) yang mengenal pasti Pujangga Melayu sebagai novel yang menonjolkan kekuatan jati diri bangsa Melayu yang didasarkan pada budaya ilmu.

Merujuk kepada label "karya persuratan" pula, analisis mendapati terdapat kajiankajian ilmiah yang yang menampilkan Pujangga Melayu sebagai sebuah karya persuratan. Antara ciri penting yang ditampilkan ialah pemikiran yang diasaskan 
pada kerangka tauhid dan taklif, selain style penulisan yang bersifat intelektual. Ciri-ciri Pujangga Melayu yang sedemikian diperlihatkan antaranya dalam kajian Ramasamy (2007) yang menggariskan pemikiran dan gaya penulisan sebagai kekuatan yang menampilkan Pujangga Melayu sebagai sebuah karya persuratan. Kajian Ungku Maimunah (2002) pula mengenal pasti kekuatan Pujangga Melayu yang menghadirkan ilmu serta meminggirkan cerita termasuk mimesis. Lebih penting ialah keutamaan terhadap ilmu yang benar di sisi Islam yang diasaskan pada kerangka tauhid sebagai ciri penting yang membolehkan Pujangga Melayu diangkat sebagai karya persuratan.

Sebagaimana yang telah dibincangkan, edisi kedua (terbitan tahun 2017) secara konsisten dan eksplisit memperagakan Pujangga Melayu sebagai sebuah novel persuratan, dengan dua ciri penting: pemikiran/wacana sebagai pengisian utama dan cerita hanya berfungsi sebagai wadah bagi mengutarakan pemikiran/wacana. Berdasarkan kepada hasil analisis berkenaan, dapat dirumuskan bahawa keduadua ciri yang digariskan pada Pujangga Melayu edisi kedua tersebut, telah sedia dikenal pasti oleh sebahagian besar kajian ilmiah terhadap Pujangga Melayu sebelum tahun 2017. Meskipun menampilkan Pujangga Melayu dengan istilahistilah seperti "novel wacana", "novel ilmu" dan "karya persuratan", namun jelas diakui bahawa kekuatan novel Mohd Affandi itu terletak pada pemikiran atau wacana yang dijadikan sebagai pengisian utama, manakala cerita pula hanya berfungsi sebagai wadah dalam mengutarakan wacana. Aspek pemikiran dan wacana ini pula dianggap sebagai manifestasi kekuatan Pujangga Melayu sebagai sebuah novel ilmu.

\section{Rujukan}

Akalily Narmi. 2020. Pujangga Melayu karya Mohd Affandi Hassan: Satu perbincangan terhadap resepsi awal penerbitannya sebagai sebuah "novel tetralogi". BITARA International Journal of Civilizational Studies and Human Sciences, 3(2): 1-19.

Krippendorff, K. 2004. Content analysis: An introduction to its methodology. Thousand Oaks: SAGE Publications.

Meor Mohamad Sollehuddin Abd Rani. 2016. Konsep "Persuratan" dan konsep "Sastera" dalam Pujangga Melayu karya Mohd Affandi Hassan. Unpublished final year project, Universiti Putra Malaysia.

Mohamad Mokhtar Hassan. 2002. Pujangga Melayu: Mohd Affandi Hassan: Satu interpretasi pengarang. Paper presented at the Majlis Diskusi Buku Pujangga Melayu. Kuala Lumpur, Februari.

Mohd Affandi Hassan. 2017. Pujangga Melayu. 2nd Ed. Kuala Lumpur: Penerbit Wadi al-Irfan.

1997. Pujangga Melayu. Kuala Lumpur: Penerbit Fajar Bakti Sdn. Bhd. 1996. Wajah Pendeta. Kuala Lumpur: Penerbit Fajar Bakti Sdn. Bhd. 
1994a. Jejak Warisan. Kelantan, Malaysia: Penerbit Tiga Puteri.

1994b. Citra Pujangga. Kuala Lumpur: Penerbit Fajar Bakti Sdn. Bhd.

1994c. Tampang Sasterawan. Kuala Lumpur: Penerbit Fajar Bakti Sdn. Bhd.

Mohd Zariat Abdul Rani. 2008. "Wacana" dan "cerita" dalam novel Pujangga Melayu karya Mohd Affandi Hassan. Pertanika Journal of Social Science and Humanities, 16(2): 187-201.

2006. Wacana seksualiti insan dalam novel Pujangga Melayu oleh Mohd Affandi Hassan. SARI, 24: 121-159.

Nur Fatiha Fadila Abu Bakar. 2014. Intelektualisme dalam lima novel Anwar Ridhwan. MA diss., Universiti Putra Malaysia.

Nurul Hilwany Che Shaffine. 2017. Ilmu dalam novel popular karya Aisya Sofea berdasarkan persuratan baru. MA diss., Universiti Putra Malaysia.

Ramasamy, R.S. 2007. Pujangga Melayu dari sudut pendekatan Persuratan Baru. MA diss., Universiti Malaya.

Shamsul Amri Baharuddin. 2002. Pujangga Melayu, pujangga idaman: Problematika identiti Melayu-Muslim Malaysia. Paper presented at the Majlis Diskusi Buku Pujangga Melayu. Kuala Lumpur, Februari.

Ungku Maimunah Mohd Tahir. 2012a. Wanita sebagai objek seks: Penanganannya dalam novel Bila Hujan Malam. GEMA Online Journal of Language Studies, 12(2): 539553.

2012b. Apabila teori feminis ternyata tidak diperlukan: Satu kajian kes. GEMA Online Journal of Language Studies, 12(4): 1213-1227.

2010. Cerita: Kedudukan dan peranannya dalam karya kreatif penulis wanita sebelum merdeka. GEMA Online Journal of Language Studies, 10(2): 117-131.

2009. Dinamika pemikiran sastera Melayu. Kuala Lumpur: Dewan Bahasa dan Pustaka.

2002. Bagaimanakah Pujangga Melayu harus ditafsirkan? Dewan Sastera, Ogos, 36-43.

United States General Accounting Office. 1996. Content analysis: A methodology for structuring and analyzing written materials. PEMD-10.3.1. Illinois: Illinois State University.

Wan Zaida Wan Yusoff. 2009. Pemikiran dalam novel Mohd Affandi Hassan: Analisis dari sudut kajian budaya. MA diss., Universiti Malaya, Kuala Lumpur.

Yuhastina. 2016. Ranah-Budi dalam novel Indonesia dan Malaysia. PhD diss., Universiti Putra Malaysia. 